\title{
THE HEMATOLOGY OF INFECTIOUS DIARRHEA *
}

\author{
CHARLES J. BLOOM, B.Sc., M.D. \\ NEW ORLEANS
}

In reviewing literature relative to this subject, the writer has found a total absence of any authentic conclusions regarding the blood in infectious diarrhea. Starr, ${ }^{1}$ Whipham ${ }^{2}$ and Keating ${ }^{3}$ make no mention of the blood whatsoever. Taylor and Wells, ${ }^{4}$ Ashby and Wright," Carmichael $^{8}$ and Oppenheim ${ }^{7}$ also failed to mention this important point. The textbooks of Donkin, ${ }^{8}$ Smith, ${ }^{9} \mathrm{Carr}^{10}$ and Cotton ${ }^{11}$ have left unsaid all matters pertaining to this subject. Even the most recent works on pediatrics, by such authorities as Koplik, ${ }^{12}$ Hutchinson, ${ }^{13}$ Chapin and Pisek, ${ }^{14}$ Rachford, ${ }^{15}$ Cautley, ${ }^{16}$ Fischer, ${ }^{17}$ McCaw, ${ }^{18}$ Rotch, ${ }^{19}$ Still, $^{20}$ Holt, $^{21}$ Garrod, Batten, Thursfield ${ }^{22}$ and Morse, ${ }^{23}$ have all left this important topic untouched. In addition, a careful survey of the works of different authorities who have made hematology a special study in the majority failed to record even a single fact on this subject. Buchanan, ${ }^{24}$ Ward, ${ }^{25}$ Schleip, ${ }^{26}$ Pappenheim $^{27}$ and Naegeli ${ }^{28}$

\footnotetext{
* Submitted for publication July 10, 1916.

* From the Boston Floating Hospital, Clinical Pathologist, August, 1914.

1. Starr: Diseases of Digestive Organs.

2. Whipham: Medical Diseases of Children.

3. Keating: Encyclopedia Diseases of Children.

4. Taylor and Wells: Diseases of Children.

5. Ashby and Wright: The Diseases of Children.

6. Carmichael: Diseases of Children.

7. Oppenheim: The Medical Diseases of Childhood.

8. Donkin: Diseases of Childhood.

9. Smith: Eustace, Diseases of Children.

10. Carr: The Practice of Pediatrics.

11. Cotton: Diseases of Infancy and Childhood.

12. Koplik: Diseases of Infancy and Childhood.

13. Hutchinson: Lectures on Diseases of Children.

14. Chapin and Pisek: Diseases of Infants and Children.

15. Rachford: Diseases of Children.

16. Cautley: Diseases of Children.

17. Fischer: Diseases of Infancy and Children.

18. McCaw: Diseases of Children.

19. Rotch: Pediatrics of Children.

20. Still: Common Disorders and Diseases of Childhood.

21. Holt: Diseases of Infancy and Childhood.

22. Garrod, Batten and Thursfield: Diseases of Children.

23. Morse: Case Histories in Pediatrics.

24. Buchanan: The Blood in Health and Disease, Oxford Medical Series.

25. Ward: Clinical Haematology.

26. Schleip: Technik der Blutuntersuchung.

27. Pappenheim: Atlas der menschlichen Blutzellen.

28. Naegeli: Blutkrankheiten und Blutdiagnostic.
} 
have ignored this question in its entirety. Gulland and Goodall ${ }^{29}$ say: "In severe cases there may be high counts from concentrations of blood. The casual conditions may cause alteration in the number or proportion of the white cells. In chronic cases there may be severe anemia." Even in the volumes of Pfaundler and Schlossmann ${ }^{30}$ there is the failure to record any of these facts.

\section{METHOD OF WORK}

The month of August proved ideal in every respect, for there were variations in temperature, and all types of infectious diarrhea were portrayed, and a sufficient number to justify conclusions under the different lines of research. For convenience and also for thoroughness it was thought preferable to divide the infectious diarrheas into three groups: Group 1 to contain the cases in which the etiologic factor was the Bacillus dysenteriae (number of cases, sixteen); Group 2, the causative factor being the $B$. welchii ( $B$. acrogenes-capsulatus) (number of cases, five), and Group 3, containing the cases with a mixed infection (number of cases, four). In all, a total of twenty-five cases were studied and watched in a detailed manner. The organisms found under the third group included $B$. welchii, $B$. paratyphosus, $B$. typhosus and streptococci. Indeed, I am glad I made these studies, because there were several important facts made out which would otherwise have been omitted.

Each morning the bacteriologist gave me a list of new cases, namely, those which were suggestive from the clinical manifestations alone. I then, on the same day, began the investigation from the hematologic standpoint. Every other day a total leukocyte count and a differential were made on the cases while in the acute stage. During the convalescent period the blood was examined not less frequently than every fourth day. In this way I studied the case from the admission and followed each one until the bacteriologic evidences for our work became negative for three successive examinations. During the period of research there were over fifty cases followed, and I have chosen twenty-five of this number, because a great many of the remaining cases proved to be other than infectious diarrhea, although clinically a number of them were thought to come within this group. The number of blood pictures per case was not less than five and not more than ten. Every day a visit in person to the individual patients was made and notations were recorded. One day out of each week the work for the previous six days was recapitulated, and if it was felt that more time was needed, the writer took an additional half day. It is hoped that

29. Gulland and Goodall: The Blood.

30. Pfaundler and Schlossman: Atlas, Diseases of Children. 
the facts obtained along this line will be the stimulus for additional work, for indeed the blood manifestations of dysentery have in the past received little attention.

\section{CLASSIFICATION}

After a careful survey of the cases in question I have endeavored to classify them from a bacteriologic point of view, ${ }^{31}$ this referring only to those which have been seen in person:

Infectious diarrhea

I. Toxic

1. Flexner
a. Severe
b. Moderate
c. Mild

II. Nontoxic

2. Welchii
a. Severe
b. Moderate
c. Mild

3. Mixed
a. Severe
b. Moderate
c. Mild

In the severe form of the toxic type there are marked prostration, coma, great loss in weight, ruby lips, temperature of 103 persisting, dejections ten to twenty-five daily, on the one hand, or two to four, on the other, and inability to retain by mouth any food whatever.

In the moderate form of this type the symptoms given above are slightly less severe, with a temperature of not over 103 , of a remitting character. Only a few dejections in this type are a rare occurrence.

In the mild form of the toxic type there is no coma, the prostration is slight, and the weight remains about uniform; there are no apparent neurologic symptoms, no perceptible loss of interest in the surroundings, and the temperature rarely reaches 101.

In the severe form of each of the two divisions of the nontoxic type the symptoms resemble those of the severe cases in the toxic group in every respect except that the coma is not as a rule so well marked and prostration does not seem to be at all proportional to the temperature and infection. The amount of fever is generally higher, particularly in the mixed infection in which the $B$. welchii is one of the organisms.

The moderate cases of these two divisions of the nontoxic group

31. From a bacteriologic stanđpoint as exhibited, August, 1914. 
differ from the severe cases only in the lower temperature, with slight prostration, and the absence of nervous symptoms.

The mild cases of the nontoxic group manifest some peculiarities. The child appears to be slightly ill, but is interested in the surroundings, and if old enough will talk, sit up in bed and do many things appertaining to its age. Diarrhea is a constant symptom, though the loss in weight is not so great as the number of dejections would lead one to expect. Bacterial manifestations are present and one finds them in almost every examination of the stool. The patients of this group have practically no abnormalities with respect to temperature, pulse or respiration; in other words, if it were not for the diarrhea you could hardly consider the children ill, yet this condition may be the forerunner of the other two types of the disease.

Table 1.-The Character of the Disease and the Result in Twenty-Five Cases of Infectious Diarrhea

\begin{tabular}{|c|c|c|c|c|}
\hline Character & Severity & Case Number * & Recovered & Died \\
\hline \multirow{3}{*}{ Toxic........... } & Severe........ & 1 D., 3 D., 4 D., 10 D., 16 D. .............. & 0 & 5 \\
\hline & Moderate.... & 11 R., 14 R., 2 D., 5 R., 6 D., 7 R., 8 D. ...... & 4 & 3 \\
\hline & & 9 R., 12 R., 13 R., 15 R. .................... & $\stackrel{4}{-8}$ & $\stackrel{0}{-8}$ \\
\hline \multirow{3}{*}{ Nontoxic....... } & (Severe........ & 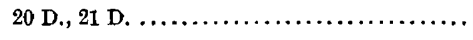 & 0 & 2 \\
\hline & Moderate.... & 22 R., 19 R. $\ldots \ldots \ldots \ldots \ldots \ldots \ldots \ldots \ldots \ldots \ldots \ldots \ldots \ldots \ldots$ & 2 & 0 \\
\hline & Mild... & 25 D., 17 R., 18 D., 23 R., 24 R. ... & $\frac{3}{-5}$ & $\frac{2}{-\frac{4}{12}}$ \\
\hline
\end{tabular}

* In this column D. signifles that the patient died, $R$. that he recovered.

\section{TEMPERATURE}

The temperature curve in infectious diarrhea is indeed variable. The first week of illness the temperature ascends gradually, reaching as a rule the maximum from the fifth to the seventh day, although occasionally the maximum will not be reached before the beginning of the second week, with a morning remission and an evening rise during the entire fever period.

In the second week of illness the maximum temperature reached is usually from 1 to 1.5 degrees less than that of the first week.

In the third week of illness the temperature rarely exceeds 100 , and most often reaches a maximum in the neighborhood of 99 and a fraction.

In the fourth week of illness the patient is generally free from fever; occasionally a slight rise to a point not exceeding 99.5 may be recorded for one day. This is due to some indiscretion and is not to be considered a part of the real curve. 
The maximum temperature over 103 means the prophecy of death. Other cases in which we have an initial temperature over 105, and this followed by a fall of from 2 to 3 degrees, for the most part terminate fatally anyway. In trying to determine whether there was any direct

Table 2.-Duration of Fever and Percentage of Deaths in Twenty-Five Cases of Infectious Diarrhta

\begin{tabular}{|c|c|c|c|}
\hline $\begin{array}{c}\text { Number } \\
\text { Oases }\end{array}$ & $\begin{array}{c}\text { Number Days } \\
\text { with Fever }\end{array}$ & $\begin{array}{l}\text { Per Cent. } \\
\text { Cases }\end{array}$ & $\begin{array}{c}\text { Per Oent. } \\
\text { Died }\end{array}$ \\
\hline $1 . . . . .$. & 20 & 4 & $\mathbf{0}$ \\
\hline $1 \ldots \ldots \ldots \ldots \ldots \ldots \ldots \ldots$ & 19 & 4 & 0 \\
\hline 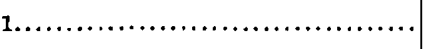 & 17 & 4 & 0 \\
\hline 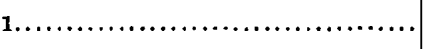 & 15 & 4 & 0 \\
\hline $4 \ldots \ldots \ldots \ldots \ldots \ldots \ldots \ldots$ & 14 & 16 & 8 \\
\hline 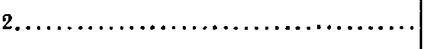 & 13 & 8 & 0 \\
\hline 1............................ & 12 & 4 & 4 \\
\hline $2 \ldots \ldots \ldots \ldots \ldots \ldots \ldots \ldots \ldots \ldots \ldots \ldots \ldots$ & 11 & 8 & 8 \\
\hline $1, \ldots \ldots \ldots \ldots \ldots \ldots \ldots \ldots \ldots$ & 10 & 4 & 0 \\
\hline 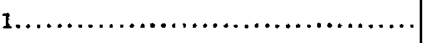 & 9 & 4 & 4 \\
\hline 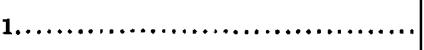 & 8 & 4 & 0 \\
\hline 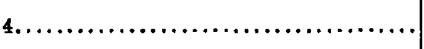 & 6 & 16 & 16 \\
\hline 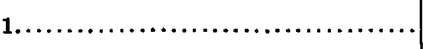 & 5 & 4 & 0 \\
\hline 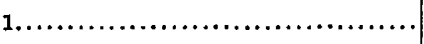 & 4 & 4 & 4 \\
\hline 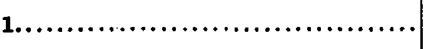 & 8 & 4 & 0 \\
\hline 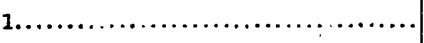 & 2 & 4 & 4 \\
\hline 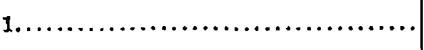 & 1 & 4 & 4 \\
\hline
\end{tabular}

table 3.-Duration of Fever Summarized in Five-Day Periods *

\begin{tabular}{|c|c|c|c|}
\hline$\underset{\text { Cases }}{\text { Number }}$ & $\begin{array}{l}\text { Number Days } \\
\text { with Fever }\end{array}$ & $\begin{array}{l}\text { Per Cent. } \\
\text { Cases }\end{array}$ & $\begin{array}{c}\text { Per Oent. } \\
\text { Died }\end{array}$ \\
\hline 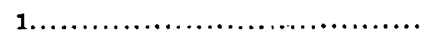 & 20 & 4 & 0 \\
\hline 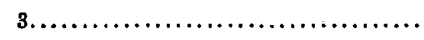 & 15 & 12 & $\mathbf{0}$ \\
\hline $10 \ldots \ldots \ldots \ldots \ldots \ldots \ldots \ldots \ldots \ldots \ldots \ldots \ldots \ldots \ldots \ldots \ldots$ & 10 & 40 & 5 \\
\hline $7 \ldots \ldots \ldots$ & 5 & 28 & 4 \\
\hline 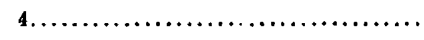 & 1 & 16 & 8 \\
\hline
\end{tabular}

* The patients averaged ten days of fever while in the hospital.

relation between the temperature and the pulse, as contrasted in typhoid fever, the following are the results obtained:

In Flexner bacillus diarrhea, as an illustration of the pulse and temperature relation, a child of 10 months showed a temperature of 104.5 and a pulse of 120 . If the pulse is taken when the child is crying, 
TABLE 4.-Percentage of Period Spent in Hospital

\begin{tabular}{|c|c|}
\hline Number Oages & $\begin{array}{l}\text { Per Oent. } \\
\text { Time in } \\
\text { Eospltal }\end{array}$ \\
\hline 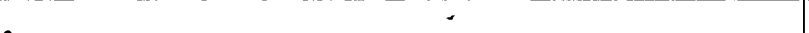 & \\
\hline 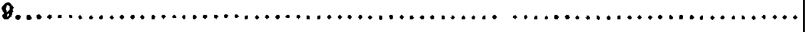 & 100 \\
\hline 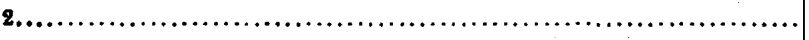 & 80 \\
\hline 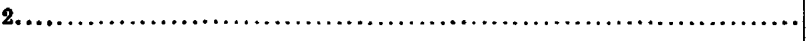 & 80 \\
\hline 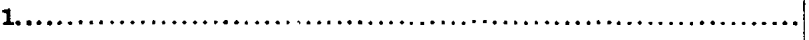 & 70 \\
\hline 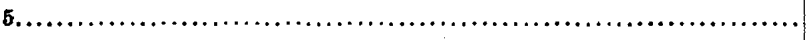 & 60 \\
\hline 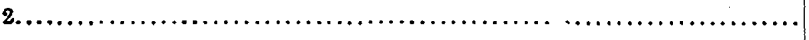 & 50 \\
\hline 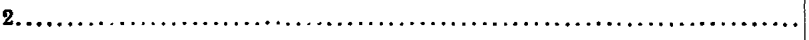 & 40 \\
\hline 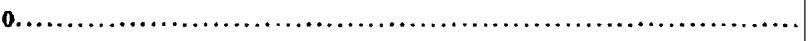 & 80 \\
\hline 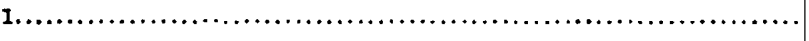 & 20 \\
\hline 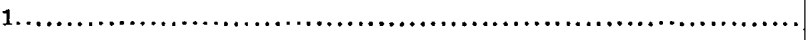 & 10 \\
\hline
\end{tabular}

TABle 5.-Summary of Percentage of Period Spent in Hospital.

\begin{tabular}{|c|c|c|}
\hline Number Oages & $\begin{array}{l}\text { Per Oent. Time } \\
\text { in Hospital }\end{array}$ & $\underset{\text { Died }}{\text { Number }}$ \\
\hline 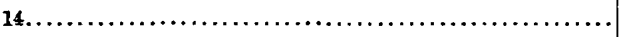 & 70 & 9 \\
\hline 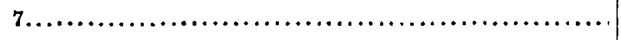 & BO & 8 \\
\hline 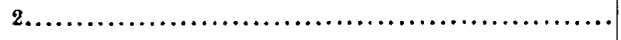 & 30 & $\mathbf{0}$ \\
\hline 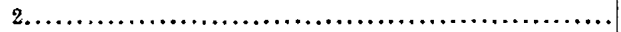 & 10 & 0 \\
\hline
\end{tabular}

TABLE 6.-RANge of Temperature

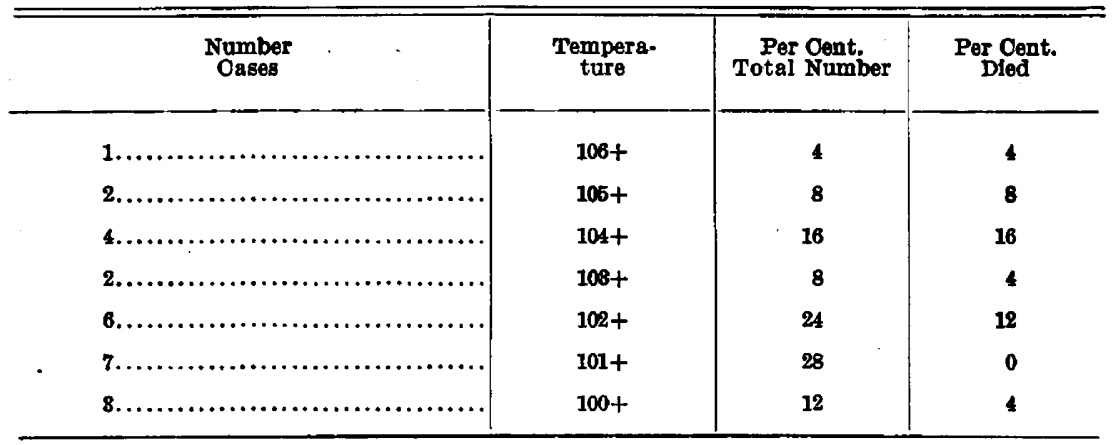

TABLE 7.-SumMaRy of RANGE of Temperature

\begin{tabular}{|c|c|c|c|}
\hline $\begin{array}{c}\text { Number } \\
\text { Cases }\end{array}$ & $\underset{\text { ture }}{\text { Tempera- }}$ & $\begin{array}{l}\text { Per Oent. } \\
\text { Total Number }\end{array}$ & $\begin{array}{c}\text { Per Oent. } \\
\text { Died }\end{array}$ \\
\hline 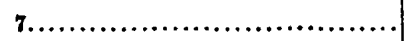 & $104+$ & 28 & 28 \\
\hline 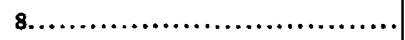 & $102+$ & 82 & 16 \\
\hline $10 \ldots \ldots \ldots \ldots \ldots \ldots \ldots \ldots \ldots \ldots \ldots \ldots$ & $100+$ & 40 & 4 \\
\hline
\end{tabular}

Downloaded From: http://archpedi.jamanetwork.com/ by a New York University User on 05/22/2015 
TABLE 8.-Duration of Illness

\begin{tabular}{|c|c|c|c|c|}
\hline \multicolumn{2}{|c|}{ Prior to Admission } & \multicolumn{3}{|c|}{ After Admission } \\
\hline Oaseas & Days & Cases & Days & \\
\hline$\underset{1}{\text { Group } 1}$ & 1 . & $\underset{2}{\text { Group }} 1$ & 2 & \\
\hline 1 & $21 / 2$ & 2 & 9. & \\
\hline 4 & 8 & 1 & 7 & \\
\hline 1 & 4 & 1 & 11 & \\
\hline 1 & C & 4 & 18 & \\
\hline 3 & 7 & 8 & 14 & \\
\hline 1 & 8 & 1 & 26 & \\
\hline 1 & 18 & 1 & 20 & \\
\hline \multirow[t]{2}{*}{$\mathbf{s}$} & 14 & 1 & 21 & \\
\hline & & 1 & 80 & \\
\hline$\underset{2}{\text { Groupd }} 2$ & 8 & Group 2 & 6 & \\
\hline 1 & 7 & 1 & 10 & \\
\hline \multirow[t]{3}{*}{2} & 14 & 1 & 11 & \\
\hline & & 1 & 12 & \\
\hline & & i & 21 & \\
\hline Group 8 & 7 & Group 8 & 10 & , \\
\hline 1 & 10 & 1 & 20 & 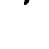 \\
\hline 1 & 14 & 2 & 21 & \\
\hline 1 & 21 & & & \\
\hline Total & 1 & Total & 2 & \\
\hline 3 & $2 \%$ & 2 & 2 & \\
\hline 6 & 8 & 1 & 6 & \\
\hline 1 & 4 & $i$ & 7 & \\
\hline 1 & 6 & 2 & 10 & \\
\hline 5 & 7 & 2 & 11 & \\
\hline 1 & 8 & 1 & 12 & \\
\hline 1 & 10 & 4 & 18 & \\
\hline 1 & 18 & 8 & 14 & \\
\hline 6 & Is & 1 & 16 . & \\
\hline 1 & 21 & 2 & 20 & \\
\hline & & 4 & 21 & \\
\hline & & 1 & $\mathbf{8 0}$ & \\
\hline
\end{tabular}

Downloaded From: http://archpedi.jamanetwork.com/ by a New York University User on 05/22/2015 
and this is the case in the majority of instances, of course the rate will be much greater; but, on the other hand, if it is taken when the child is at rest, as a rule a high temperature and a low pulse will be obtained, very similar to the condition in typhoid.

In the second or Welch's bacillus group the results obtained vary markedly from those of the former. As an illustration, a child of

TABle 9.-Total Duration of Illness Arranged by Groups

\begin{tabular}{|c|c|c|c|}
\hline Case & Duration, Days & Oase & Duration, Days \\
\hline $\begin{array}{l}\text { Group } 1 \\
\quad 1 \ldots \ldots \ldots \ldots \ldots \ldots \ldots \ldots \ldots\end{array}$ & 1 & $\underset{1 \ldots \ldots \ldots \ldots \ldots \ldots \ldots \ldots}{\operatorname{Group}} 2$ & 18 \\
\hline $2 \ldots \ldots \ldots \ldots \ldots \ldots \ldots \ldots$ & 14 & $1, \ldots \ldots \ldots \ldots \ldots \ldots \ldots \ldots$ & 18 \\
\hline $2, \ldots \ldots \ldots \ldots \ldots \ldots \ldots$ & 16 & $1 . \ldots \ldots \ldots \ldots \ldots \ldots \ldots \ldots$ & 20 \\
\hline 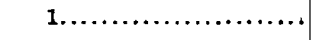 & 17 & $1, \ldots \ldots \ldots \ldots \ldots \ldots \ldots \ldots$ & 26 \\
\hline $1, \ldots \ldots \ldots, \ldots, \ldots, \ldots, \ldots$ & 18 & $1, \ldots \ldots, \ldots, \ldots, \ldots, \cdots$ & 45 \\
\hline $2 \ldots \ldots \ldots \ldots \ldots \ldots \ldots, \ldots$ & 20 & Group 3 & \\
\hline $1, \ldots, \ldots, \cdots, \cdots, \cdots$, & 21 & $1, \ldots \ldots \ldots \ldots \ldots \ldots \ldots \ldots$ & 17 \\
\hline $2, \ldots \ldots \ldots \cdots \cdots \cdots \cdots$ & 23 & $1 \ldots \ldots \ldots \ldots \ldots \ldots \ldots \ldots$ & 30 \\
\hline $1 \ldots \ldots \ldots \ldots \ldots$ & 26 & $1 \ldots \ldots \ldots \ldots \ldots \ldots, \ldots$ & 85 \\
\hline $1, \therefore \ldots \cdots \cdots \cdots, \cdots, \cdots, \cdots$ & 29 & $1 \ldots \ldots \ldots \ldots \ldots \ldots \ldots$ & 42 \\
\hline $1 \ldots \ldots \ldots \ldots \ldots \ldots \ldots \ldots$ & 44 & & \\
\hline
\end{tabular}

TABLE 10.-Total Duration of Illness *

\begin{tabular}{|c|c|c|c|}
\hline Case & Duration, Days & Case & Duration, Days \\
\hline $1 . \ldots \ldots \ldots \ldots \ldots \ldots \ldots$ & 11 & $2 \ldots \ldots \ldots \ldots \ldots \ldots \ldots \ldots$ & 26 \\
\hline $1 \ldots \ldots \ldots \ldots \ldots \ldots \ldots$ & 13 & $1 \ldots \ldots \ldots \ldots \ldots \ldots \ldots, \ldots$ & 29 \\
\hline $2 \ldots \ldots \ldots \ldots \ldots \ldots \ldots$ & 14 & $1 \ldots \ldots \ldots \ldots \ldots \ldots \ldots$ & 30 \\
\hline $2 \ldots \ldots \ldots \ldots \ldots \ldots \ldots$ & 16 & $1, \ldots \ldots \ldots \ldots \ldots \ldots \ldots$ & 35 \\
\hline $2 \ldots \ldots \ldots \ldots \ldots \ldots \ldots \ldots$ & 17 & $1, \ldots \ldots \ldots \ldots \ldots \ldots \ldots$ & 42 \\
\hline $2 \ldots \ldots \ldots \ldots \ldots \ldots \ldots$ & 18 & $1, \ldots \ldots \ldots \ldots \ldots$ & 44 \\
\hline $8 \ldots \ldots \ldots \ldots \ldots \ldots \ldots$ & 20 & $1 \ldots \ldots \ldots \ldots \ldots \ldots \ldots \ldots$ & 45 \\
\hline $1 . \ldots \ldots \ldots \ldots \ldots \ldots \ldots$ & 21 & & - \\
\hline $2 . \ldots \ldots \ldots \ldots \ldots \ldots \ldots \ldots$ & 23 & Average............... & 23 \\
\hline
\end{tabular}

* Oase 5 has been omitted.

7 months showed a temperature of 100 and a pulse of 150 . This typifies a peculiar combination, namely, a rather low temperature and a greatly accelerated pulse.

The cases under the group of mixed infection simulate those classified under the previous one, with the exception that the pulse is more greatly accelerated, particularly if the mixed infection contains both the $B$, welchii and streptococci. 
Fever is one of the symptoms on which'a degree of prognostication can be based. The limits were from 100 to 106 and a fraction. All patients who had a temperature above 104 died, and a few of those whose temperature reached but a fraction above 102 succumbed.

Of those who died, 77 per cent. succumbed in less than twenty days, and the remaining 23 per cent. died between the twenty-first and twenty-sixth days. Of those who recovered, 27 per cent. were sick under twenty days, 28 per cent. between twenty-one and thirty days, 18 per cent. between thirty and forty days and 28 per cent. between forty and fifty days.

\section{TYPICAL CASES}

CASE 13 (Group 1).-W. D. was the youngest of three children, having two sisters, aged 3 and 4 years, respectively. His father was 26 and his mother 23 years old, and both give a history of good health. There had been no known exposure to tuberculosis or to infectious diseases and no history of syphilis. The child was born at full term in normal delivery and was not ill until February, when he had bronchitis for three weeks. He was breast fed for ten months and after that time received various modifications of condensed milk with crackers and bread added to the diet.

TABLE 11.-Blood Finding in the Case of W. D.

\begin{tabular}{c|c|c|c|c|c|c}
\hline \hline Date & Leukocytes & Large & Small & Neutrophils & $\begin{array}{c}\text { Transition- } \\
\text { als }\end{array}$ & Türck's Cells \\
\hline $8 / 2 / 14$ & 8,600 & 7 & 19 & 68 & 1 & 5 \\
$8 / 4 / 14$ & 12,100 & 9 & 36 & 49 & 5 & 1 \\
$8 / 8 / 14^{*}$ & 9,400 & 4 & 32 & 60 & $\ldots$ & 4 \\
$8 / 11 / 14$ & 14,800 & 6 & 26 & 60 & 2 & 0 \\
$8 / 17 / 14$ & 10,600 & & & & & \\
$8 / 20 / 14$ & 12,800 & 8 & 60 & 32 & & \\
$8 / 22 / 14$ & 10,400 & 10 & 36 & 48 & & \\
$8 / 25 / 14$ & 12,400 & 2 & 56 & 36 & & \\
$8 / 29 / 14$ & 16,600 & 2 & 42 & 56 & & \\
$8 / 30 / 14$ & 15,800 & 4 & 44 & 52 & & \\
\hline
\end{tabular}

* Entered on the sixteenth day of illness, convalescent from Aug. 8, 1914, on.

He had been ill for two weeks at the time of admission, suffering with vomiting and diarrhea, the vomiting immediately following the intake of food. The diarrhea consisted of fifteen movements in twenty-four hours, green in color, watery in consistency, foul in odor, and containing blood and mucus. He had had fever one day, seemed somewhat prostrated and slept poorly.

Physical examination showed nutrition and development good. The cheeks were somewhat flushed and the general appearance indicated that the child was ill. The anterior fontanel was open, measuring $1.5 \mathrm{by} 1.5 \mathrm{~cm}$. There was a slight rosary, but enlargement of the epiphyses and rigidity and retraction of neck were negative. The pupils and the eyes in general, the tongue and the mouth seemed normal. He had four teeth above and two below. There were no enlarged glands and the drums of the ears were not pathologic. The heart was normal for a person of the patient's age. The left border of dulness was 
$4.5 \mathrm{~cm}$. to the left of the midsternal line, and $0.5 \mathrm{~cm}$. inside the nipple line; the right border was $2.5 \mathrm{~cm}$. to the right of the midsternal line. The sounds were regular and no murmurs were heard. The lungs showed no pathologic conditions. The abdomen protruded slightly, and there were physical signs of tympanites. The liver dulness extended from the fifth rib to $2 \mathrm{~cm}$. below the edge of the costal border. The genitalia were negative. The skin was soft, elastic, warm and of good color.

Laboratory findings on Aug. 13, 1914, showed B. dysenteriae-Flexner positive; von Pirquet negative on Aug. 6, 1914.

The blood findings in the case of W. D. may be compared to those of another patient with the toxic type of moderate severity.

CASE 19 (Group 2).-R. G. was the youngest of four children. Her father died at the age of 29 from a paralytic stroke. The brothers and the sister were in good health. The mother gave a history of one miscarriage. There had been no known expcsure to tuberculosis or infectious diseases. The child's birth weight was 10 pounds. She had an easy birth, being born at full term without the use of instruments. She was nursed for one month, and then Mellen's food in variable proportions was substituted until the child was 6 months of age. After that time she took bread and crackers and modifications of whole milk.

TABle 12.-Blood Findings in a Case of Toxic Type of Moderate Severity

\begin{tabular}{c|c|c|c|c|c|c}
\hline \hline Date & Leukocytes & Large & Small & Neutrophils & $\begin{array}{c}\text { Transition- } \\
\text { als }\end{array}$ & Turck's Oells \\
\hline $8 / 8 / 14^{*}$ & 5,800 & 12 & 44 & 40 & 4 & 0 \\
$8 / 11 / 14$ & 8,600 & 8 & 20 & 72 & 0 & 0 \\
$8 / 14 / 14$ & 9,000 & 6 & 42 & 52 & 0 & 0 \\
$8 / 17 / 14$ & 7,600 &. &.. &.. & 0 & 0 \\
$8 / 20 / 14$ & 6,600 & 2 & 64 & 34 & 0 & 0 \\
$8 / 22 / 14$ & 8,800 & 2 & 30 & 68 & 0 & 0 \\
$8 / 25 / 14$ & 6,800 & 2 & 40 & 58 & 0 & 0 \\
$8 / 28 / 14$ & 6,400 & 0 & 50 & 46 & 2 & 2 \\
$8 / 29 / 14$ & 5,800 & 2 & 50 & 46 & 2 & 0 \\
\hline
\end{tabular}

* Entered on the ninth day of illness.

Three weeks before the child was examined, when she was recovering from pertussis, she developed diarrhea. With the diarrhea there were fever and vomiting. Vomiting persisted after the initial attack, being irregular in frequency and occurring immediately after feedings. The amount vomited equaled the amount of food taken, the vomitus being curdled. The diarrhea was very severe, the movements numbering from ten to fourteen a day, green in color, watery in consistency, foul in odor and containing a few curds, much blood and a large quantity of mucus, but the prostration was moderate in degree.

Physical examination showed the child to be of poor development and nutrition. Her general appearance, however, was fair. Her head was round, the posterior fontanel was closed and there was no craniotabes present. The anterior fontanel measured 3.5 by $3 \mathrm{~cm}$. The pupils were clear and responded to light and accommodation. The tongue and mouth seemed normal. The throat was clean and there was no evidence of dentition. There was no discharge from the ears; the glands were negative. Heart, lungs, abdomen and genitalia gave no evidence of a pathologic condition. The liver was slightly enlarged and was $2 \mathrm{~cm}$. below the costal border. The reflexes were present, but not exaggerated. There was no paralysis or muscular spasm, and Kernig and Babinski signs were 
absent. The skin was dry, soft and elastic. She had a slight erythema on her back and her buttocks were excoriated.

On Aug. 12, 1914, laboratory examination showed $B$. welchii triple plus.

CASE 23 (Group 3).-E. B. was the youngest child of healthy parents of French extraction. The other children were in good health. The family history was entirely negative. The child was born at full term and was normal at birth. The mother thought the child weighed 7 pounds at birth. The baby, unfortunately, received no breast milk. A modification of whole milk of the formula 2-6-1.6 was given her for two weeks. This, however, did not agree with her. Malted milk was next tried in varying proportions, and the child seemed to thrive much better.

TABLE 13.-Laboratory Findings in the Case of R. G.

\begin{tabular}{c|c|c|c|c|c|c}
\hline Date & Leukocytes & Large & Small & $\begin{array}{c}\text { Transltion. } \\
\text { als }\end{array}$ & Neutrophils & Myelocytes \\
\cline { 2 - 6 } $8 / 12 / 14$ & 9,400 & 2 & 50 & 2 & 46 & \\
$8 / 18 / 14$ & 17,600 & 12 & 54 &.. & 34 & \\
$8 / 15 / 14$ & 10,800 & 2 & 26 & 4 & 62 & 6 \\
$8 / 19 / 14$ & 18,000 & 2 & 82 &.. & 16 & \\
$8 / 21 / 14$ & 13,600 & 4 & 60 &.. & 34 & \\
$8 / 24 / 14$ & 20,500 & 4 & 86 &.. & 10 & \\
$8 / 26 / 14$ & 16,400 & 4 & 50 &.. & 56 & \\
$8 / 29 / 14$ & 9,400 &.. & 40 &.. & 60 & \\
\hline
\end{tabular}

TABLE 14.-Laboratory Findings in the Case of E. B.

\begin{tabular}{c|c|c|c|c|c|c|c}
\hline \hline Date & Leukocytes & Large & Small & $\begin{array}{c}\text { Neutro- } \\
\text { phils }\end{array}$ & $\begin{array}{c}\text { Transi- } \\
\text { tionals }\end{array}$ & $\begin{array}{c}\text { Eosino- } \\
\text { phils }\end{array}$ & $\begin{array}{c}\text { Türck's } \\
\text { Cells }\end{array}$ \\
\hline $8 / 13 / 14$ & 10,200 & 0 & 40 & 60 & & & \\
$8 / 15 / 14$ & 30,400 & 12 & 36 & 52 & 4 & & \\
$8 / 19 / 14$ & 16,800 & 4 & 28 & 76 & 2 & & \\
$8 / 21 / 14$ & 15,000 & 2 & 34 & 64 & & & \\
$8 / 24 / 14$ & 12,400 & 2 & 60 & 36 &.. & 2 & \\
$8 / 26 / 14$ & 14,200 & 4 & 56 & 36 & 4 & & \\
$8 / 29 / 14$ & 14,000 & 2 & 52 & 44 &. &. & 2 \\
\hline
\end{tabular}

Two days prior to admission the child started to vomit forcibly, and each spell of vomiting was accompanied by a dejection. This occurred with each feeding. At the time of entrance the diarrhea was marked, there being from eight to ten dejections, containing the usual ingredients of an infectious diarrhea stool, namely, blood, pus and mucus. Her prostration was slight. She had some fever, but she slept fairly well; her appetite was variable.

Physical examination showed that considering the poor way in which she had been nourished in the past, her development and nutrition were fairly good. Her general appearance and color, while not normal, had not the aspects of a serious infection. The anterior fontanel was still open, otherwise the head was normal. Rigidity and retraction of the neck were negative. There were not as yet any of the signs of rickets. The pupils and the eyes in general seemed normal. The tongue was slightly coated and mouth was clean. There were no 
teeth present. Glandular enlargement was not present. The heart, lungs and liver were negative. The abdomen was somewhat pendulous. The reflexes were diminished. No edema was present. The skin was clear, clean, flaccid and smooth.

Examination of stools made Aug. 15, 1915, showed the presence of B. welchii and streptococci.

\section{SUMMARY}

Total Leukocyte Counts (Weekly Average)

1. There was a progressive weekly increase in the total leukocyte count.

2. Contrasted with this fact, there was a corresponding fall in the temperature.

3. The range of the leukocyte count was least with Flexner bacillus infection and greatest with the mixed infection.

4. Group 1 is characterized by having a normal leukocyte count at the onset, followed within from two to four days by a marked leukopenia, which persists until the convalescent period, unless there are complications. (The normal blood count is from 9,000 to 11,000 [Hayem] for children between the ages of 6 months and 5 years.) Group 2 is characterized by a rather high leukocyte count throughout the illness. Group 3 shows a marked leukocytosis from the beginning, slightly decreasing toward the middle of the illness, but always showing an increased cell count. If one of the organisms is the typhoid or paratyphoid bacillus, combined with $B$. welchii, then the leukocytosis will be diminished; but, on the other hand, if the $B$. welchii is combined with streptococci, a greater leukocyte count than Group 2 will be noticed.

\section{Differential Counts}

\section{Group I (Sixteen Cases, B. dysenteriae, Flexner)}

1. High neutrophilic count for the first two weeks, with corresponding low, small mononuclear count.

2. Large mononuclears increased throughout.

3. Rarity of eosinophils and basophils.

4. Slight increase in neutrophils and a slight decrease of the small mononuclears for the third and the fourth week.

5. Generally a rise follows a remission of the neutrophils and vice versa for the lymphocytes.

6. Myelocytes were present in five cases.

7. Transitional cells were present, particularly when a toxic element was in evidence.

$$
\text { Group } 2 \text { (Five Cases, B. welchii) }
$$

1. Slight increase of neutrophils.

2. Absence of eosinophils. 


\section{Group 3 (Four Cases, Mixed Infection)}

1. A small increase in the neutrophils, and a corresponding decrease in the small mononuclears.

2. The large mononuclears show a greater increase than in the two previous groups.

\section{Average Differential Counts, Groups I, 2 and 3 (Twenty-Five Cases)}

1. Large mononuclears increased throughout.

2. Transitional cells are found in about 30 per cent. of the cases, particularly in Group 1 (severe and mild type).

3. Practical absence of eosinophils and basophils.

4. Presence of the so-called Türck's cell in about 20 per cent. of the cases.

5. Large mononuclears, giant cell types, were seen frequently in about 25 per cent. of the cases. They were, however, but few in number. The nuclei were deeply stained by both Giemsa's and Wright's stains.

6. Small mononuclears, Türck's ${ }^{32}$ cells, were present. Schleip called my attention to a cell somewhat larger than the small mononuclear and having in addition more protoplasm and less nucleus.

7. Neutrophils showed in many instances a slight degree of transition, but not sufficient to classify them in this group.

8. Basophils were not present.

9. Eosinophils were present in a small number of cases.

10. Transitional cells were present in cases in which the toxemia was more pronounced.

3529 Prytania Street.

32. My attention was called to these cells while reading a book by Schleip (Footnote 26). Personally, I do not see a sufficient reason for a separate division; these were simply recorded as a matter of interest. 